\title{
Removal Efficiency and the Mineralization Mechanism During Enhanced Bioventing Remediation of Oil-Contaminated Soils
}

\author{
Jianli Jia ${ }^{1 *}$, Shenwei Zhao ${ }^{1}$, Lei Hu${ }^{1}$, Yapeng Wang ${ }^{1,2}$, Linying Yao ${ }^{1}$, \\ Ying Liu ${ }^{3}$, Zhipo Yuan' \\ ${ }^{1}$ School of Chemical and Environmental Engineering, China University of Mining and Technology, Beijing, China \\ ${ }^{2}$ School of Environment, Tsinghua University, Beijing, China \\ ${ }^{3}$ Yanqing Country Water Authority, Beijing, China
}

Received: 15 March 2016

Accepted: 27 May 2016

\begin{abstract}
The environmental challenge of crude oil-contaminated soil is difficult to address due to its complicated components and the mechanism of material transformation. In order to study the bioremediation of soil contaminated by crude oil, we designed five simulation test systems: a sterilization system, an oxygenated and water-controlled system, a nitrogen $(\mathrm{N})$ /phosphorus $(\mathrm{P})$ adjusted system, a broth-added system, and a double-broth-added system. The results show that the highest removal of crude oil from soil was increased to $34.23 \%$ by regulating the micro-ecological environment after 91 days in a simulation system. Regulating $\mathrm{N}$ and $\mathrm{P}$ can effectively strengthen the mineralization action of microorganisms on crude oil. Biodegradation had the most effect on the removal of oil, accounting for more than $58 \%$ of the total removal. Moreover, mineralization was dominant in biodegradation. Degradation of crude oil components was alkanes-based, accounting for 50 to $80 \%$ of total oil removal. By regulating moisture, temperature, oxygen content, N/P levels, and enrichment broth, the half-life of crude oil in a simulation system can be shortened to 182 days.
\end{abstract}

Keywords: removal efficiency, mineralization, bioremediation, crude oil, simulation system

\section{Introduction}

With the continuous development of the global industrialization process, the demands of petroleum products are increasing [1]. However, there is a lack of oil exploration, storage, transportation, processing, and use. In addition, sudden oil spill accidents result in a large amount of oil being released into the soil environment -

*e-mail: jj1@cumtb.edu.cn not only the petroleum but also related products - which poses a huge threat to human health and destroys the natural ecosystem [2-3].

In the restoration techniques of petroleumcontaminated soil, biotechnology has gained attention and importance because of its low cost, little secondary pollution, and slight destruction of existing soil composition [4-6]. Domestic and foreign researchers have worked to develop a foundation of knowledge on bioremediation of petroleum-contaminated soil. In one such study, microbial remediation, phytoremediation, and 
microbial/phytoremediation were used to decontaminate an aged and heavily contaminated soil, and the results showed that the efficiency of polycyclic aromatic hydrocarbon (PAH) removal by microbial/phytoremediation (69.6\%) was the most effective [7]. A fungal bioremediation method was developed to treat soils heavily contaminated with PAHs and resulted in the removal of $96 \%$ of 4-ring PAHs and 39\% of 5- and 6-ring PAHs in the microcosms inoculated with Phanerochaetec velutina after three months [8].

We investigated the growth characteristics of seven bacterial strains isolated from oil-contaminated soil in northern Shanxi Province, as well as their degradation efficiencies for various hydrocarbons. Some of them (Neisseria sp., Plesiomonas sp., Xanthomonas sp., Azotobacter sp., and Flavobacterium sp.) were able to use short-chain hydrocarbons and aromatic hydrocarbons as cultivation medium, and were a preferential choice to be used for bioremediation of oil-contaminated soil [9]. The treatments with inorganic or organic nutrients are equally effective over almost 30 days, where $\mathrm{C}_{12}-\mathrm{C}_{35} n$-alkanes were degraded more than $97 \%$ and polyromantic hydrocarbons with two or three rings were degraded more than $95 \%$ within 45 days [10]. Surfactant foam containing psychrophilic oil-degrading microbes and nutrients were used to enhance bioremediation of oil-contaminated soil in cold conditions. The removal efficiencies in total petroleum hydrocarbon (TPH) over 30 days were $46.3 \%$ for land farming and $73.7 \%$ for foam spraying [11]. Some researchers did experiment only on the bioremediation of toluene [12], and some researchers studied the bioventing in a residual clayey soil contaminated with a blend of biodiesel and diesel oil [13]. However, there was little research on the bioremediation of the soil contaminating oil with complicated components. On the other hand, the mechanism of bioremediation was seldom studied, which was one purpose of this article.

Daqing Oilfield was chosen as a study site of oilcontaminated soil for biological remediation testing. Through constructing simulation test systems of biological remediation for oil-contaminated soil, the efficiency of petroleum-degradation by microorganisms was evaluated, and the role of mineralization and intermediates in the biodegradation was explored. In addition, the relationship between the effects of bioremediation and factor levels of non-biologicals was modeled, which provided theoretical and technical support for bioremediation project implementation in a wide range of oil-contaminated oilfield sites in China.

\section{Material and Methods}

Soils

The soil used in this study was from oil-contaminated ground surfaces ranging from $0 \mathrm{~cm}$ to $25 \mathrm{~cm}$ around upstream Nan gang bubble oil wells in the Daqing Oilfield $\left(124^{\circ} 52^{\prime} 48^{\prime \prime} \mathrm{E}, 46^{\circ} 23^{\prime} 60^{\prime \prime} \mathrm{N}\right)$. The soil was silt loam of moderate permeability and water retention, and good ventilation after general analysis. Table 1 shows the biological and non-biological characteristics of the soils.

\section{Enrichment Broth}

The enrichment broth was made from the soil samples, which provided the indigenous microorganism and that can also decrease the environmental safety risk in bioremediation.

We put a $2 \mathrm{~g}$ soil sample into the deionized water that had been sterilized and was then vibrated for two hours. In the preparation of enriching the broth we chose paraffin as the culture medium for the degrading bacteria enrichment because the alkane accounts for $50 \%$ in the total oil in the polluted soil. Then we added $5 \mathrm{~mL}$ mixed liquid containing microorganisms into $500 \mathrm{~mL} 11 \%$ paraffin culture medium $(\mathrm{m} / \mathrm{v})$, and shake cultivation at $37^{\circ} \mathrm{C}$ for one week. We added the prepared enrichment broth into the correspondent simulation system.

\section{An Enhanced Bioventing Remediation System}

Based on the dynamic oxygen filling of the soil, we designed a closed, enhanced bioventing remediation system of petroleum-contaminated soil to reduce heterogeneity of the soil medium system and study the efficiency and intermediate process of biodegradation of petroleum with complicated components. The intermediate process of crude oil biodegradation, the role of mineralization in the biodegradation, and the mechanism of pollutant degradation were measured. We designed four systems, including an oxygenated and water-controlled system, an N/P-adjusted system, a broth-added system, and a doublebroth-added system. At the same time, a sterilization system was set up as a comparison with the same test conditions. With a view to the extremely outstanding non-homogeneity of the soil medium, we designed eight

Table 1. Characteristics of the soil used in the laboratory experiments.

\begin{tabular}{|c|c|c|c|c|c|c|c|c|c|c|}
\hline Item & $\mathrm{pH}$ & $\begin{array}{c}\text { Oil content } \\
(\%)\end{array}$ & $\begin{array}{c}\text { Moisture } \\
\text { content } \\
(\%)\end{array}$ & $\begin{array}{c}\text { Organic } \\
\text { matter } \\
(\%)\end{array}$ & $\begin{array}{c}\mathrm{TN} \\
(\mathrm{mg} / \mathrm{kg})\end{array}$ & $\begin{array}{c}\mathrm{TP} \\
(\mathrm{mg} / \mathrm{kg})\end{array}$ & $\begin{array}{c}\text { Alkane } \\
(\%)\end{array}$ & $\begin{array}{c}\text { Arene } \\
(\%)\end{array}$ & $\begin{array}{c}\text { Colloid } \\
(\%)\end{array}$ & $\begin{array}{c}\text { Asphalt } \\
(\%)\end{array}$ \\
\hline Soil & 7.89 & 5.05 & 5.97 & 9.67 & 750 & 580 & 42.06 & 22.48 & 20.94 & 16.60 \\
\hline
\end{tabular}




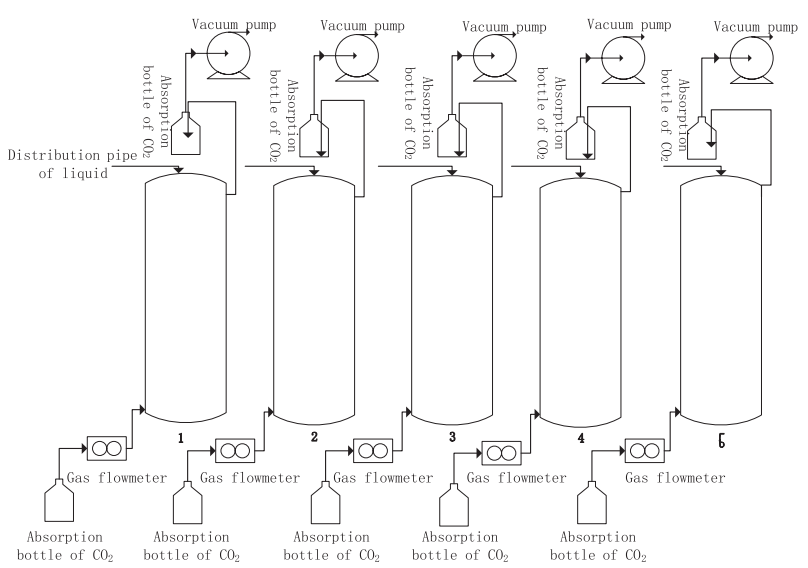

Fig. 1. Diagram of the simulation system.

Note: 1. Sterilization system; 2. Oxygenated and water-controlled system; 3. N/P-adjusted system; 4. Broth-added system; 5. Double-broth-added system.

sampling holes at the same elevation on both sides of each simulation system to collect soil samples at different reaction times.

A sterilization system was used for studying the decrease in crude oil caused by volatilization in the bioremediation process, which was a comparison for evaluating the bioremediation effects of different strengthening measures of other simulation systems. An oxygenated and water-controlled system was used to evaluate microbial degradation of petroleum contaminants under the control of oxygen, temperature, and water. The $\mathrm{N} / \mathrm{P}$ adjusted system was used to study the degradation processes and mechanisms of pollutants after adding $\mathrm{N}$ and $\mathrm{P}$ nutrients on the basis of controlling measurements of the oxygenated and water-controlled system. The broth-added and double-broth-added systems were used to study the impact of different amounts of enrichment broth on efficiency; the utilization and the mechanisms of petroleum biodegradation on the basis of the N/P-adjusted system strengthened measures.

For each system, vacuum pumping provided oxygen and gas pressure throughout the process. An absorption bottle at the inlet filtrated and purified $\mathrm{CO}_{2}$ in the air, and a gas distribution plate was set on the bottom of the reactor. We filled the soil samples uniformly to achieve evenly distributed oxygen in the soil across a $2 \mathrm{~mm}$ sieve. An absorption bottle containing $\mathrm{NaOH}$ solution $(0.5 \mathrm{~mol} / \mathrm{L})$ was set on the system outlet to absorb the $\mathrm{CO}_{2}$ produced by mineralization. This was used to measure and calculate the degree of mineralization of the crude oil in soil.

Fig. 1 shows the diagram of a simulation system. Table 2 shows the structural parameters of the reactors, and Table 3 details the experimental design of the simulation system.

\section{Analysis Methods}

\section{Content and Components of Crude Oil Analysis}

Crude oil content was determined using ultrasonic wave and Soxhlet extraction [14]. Oil components were determined using column chromatography. Volatile

Table 2. Structural and operating parameters of the reactor in the simulation systems.

\begin{tabular}{|c|c|c|c|c|c|c|c|}
\hline \multirow{2}{*}{$\begin{array}{c}\text { Structural } \\
\text { parameters }\end{array}$} & $\begin{array}{c}\text { Inner Diameter } \\
(\mathrm{cm})\end{array}$ & $\begin{array}{c}\text { Height } \\
(\mathrm{cm})\end{array}$ & $\begin{array}{c}\text { Height of } \\
\text { the lining } \\
(\mathrm{cm})\end{array}$ & $\begin{array}{c}\text { Packing } \\
\text { density } \\
\left(\mathrm{g} / \mathrm{cm}^{-3}\right)\end{array}$ & $\begin{array}{c}\text { Height difference of } \\
\text { sampling hole } \\
(\mathrm{cm})\end{array}$ & $\begin{array}{c}\text { Diameter of } \\
\text { distribution } \\
\text { hole of gas } \\
(\mathrm{mm})\end{array}$ & $\begin{array}{c}\text { Center } \\
\text { distance of } \\
\text { distribution } \\
\text { hole of gas } \\
(\mathrm{mm})\end{array}$ \\
\cline { 2 - 8 } \\
$\begin{array}{c}\text { Operating } \\
\text { parameters }\end{array}$ & $\begin{array}{c}\text { Evacuation } \\
\text { time } \\
(\mathrm{min})\end{array}$ & $\begin{array}{c}\text { Reaction } \\
\text { time } \\
(\mathrm{min})\end{array}$ & $\begin{array}{c}\text { Pumping } \\
\text { rate } \\
(1 / \mathrm{min})\end{array}$ & $\begin{array}{c}\mathrm{O}_{2} \text { content of } \\
\text { system } \\
(\%)\end{array}$ & $\begin{array}{c}\text { Concentration of } \\
\text { NaOH absorbing } \\
\text { liquid } \\
(\mathrm{mol} / \mathrm{l})\end{array}$ & 2 & 5 \\
\cline { 2 - 8 } & 30 & 210 & 2.5 & $\geq 5$ & $\approx 0.5$ & & \\
\hline
\end{tabular}

Table 3. Experimental design of simulation systems using petroleum-contaminated soil.

\begin{tabular}{|c|c|c|c|c|c|c|}
\hline System & $\begin{array}{c}\text { Soil weight } \\
(\mathrm{kg})\end{array}$ & $\begin{array}{c}\mathrm{NaOH} \\
(\mathrm{kg})\end{array}$ & $\begin{array}{c}\mathrm{NaCl} \\
(\mathrm{kg})\end{array}$ & $\begin{array}{c}\mathrm{NH}_{4} \mathrm{NO}_{3} \\
(\mathrm{~g})\end{array}$ & $\begin{array}{c}\mathrm{KH}_{2} \mathrm{PO}_{4} \\
(\mathrm{~g})\end{array}$ & $\begin{array}{c}\text { Enrichment broth } \\
(\mathrm{ml})\end{array}$ \\
\hline Sterilization & 10.8 & 3.24 & 1.08 & - & - & - \\
\hline Oxygenated and water-controlled & 15 & - & - & - & - & - \\
\hline N/P-adjusted & 15 & - & - & 34.5 & 4.95 & - \\
\hline Broth-added & 15 & - & - & 34.5 & 4.95 & 400 \\
\hline Double-broth-added & 15 & - & - & 34.5 & 4.95 & 800 \\
\hline
\end{tabular}


organic chemicals (VOCs) and prediction of petroleum half-life are discussed in detail below.

\section{Measuring the Degree of Crude Oil Mineralization}

Two $\mathrm{ml}$ of $1 \mathrm{~mol} / \mathrm{L} \mathrm{BaCl}_{2}$ solution was added to $2 \mathrm{ml}$ $\mathrm{NaOH}$ absorption solution at different reaction times. Next, two drops of a phenolphthalein indicator were added and the solution was titrated with the standard $\mathrm{HCl}$ solution until the color changed. The concentrations of $\mathrm{NaOH}$ at different reaction points were measured and then calculated as shown in Equation (1):

$$
C(\mathrm{NaOH})=\frac{C(\mathrm{HCl}) \times V(\mathrm{HCl})}{V(\mathrm{NaOH})}
$$

... where $\mathrm{NaOH}$ concentrations are in $\mathrm{mol} / \mathrm{L}$, and $\mathrm{NaOH}$ and $\mathrm{HCl}$ volume are in $\mathrm{ml}$.

According to the determined total consumption of $\mathrm{NaOH}$ by $\mathrm{CO}_{2}$, the total amount of $\mathrm{CO}_{2}$ produced was calculated based on the consumption of per $1 \mathrm{ml} \mathrm{NaOH}$ $(0.1 \mathrm{~mol} / \mathrm{L})$, which was equal to $2.2 \mathrm{mg} \mathrm{CO}_{2}$ produced. This standardized the conversion of oil mineralization in a volume of oil into units of $\mathrm{mg} / \mathrm{kg}$ and could be referenced to the dry soil.

From gas chromatography-mass spectrometer (GCMS) analysis and column chromatography of crude oil [15], oil was composed mainly of low-carbon aromatics and high-carbon alkane, whose formula was possibly $\mathrm{C}_{\mathrm{m}} \mathrm{H}_{2 \mathrm{~m}-6}$ and $\mathrm{C}_{\mathrm{n}} \mathrm{H}_{2 \mathrm{n}+6}$, respectively ( $\mathrm{m}$ and $\mathrm{n}$ were generally large), which were also the components of petroleum easily utilized by microbes. Based on this, the biochemical reactions of residual oil in soil can be expressed by Equation (2):

$$
\mathrm{C}_{m} \mathrm{H}_{2 m-6} / \mathrm{C}_{n} \mathrm{H}_{2 n+6}+\mathrm{O}_{2} \rightarrow \mathrm{m} / n \mathrm{CO}_{2}+\mathrm{H}_{2} \mathrm{O}+\text { others }
$$

...according to which the ratio of carbon to hydrogen from the petroleum in soil was $m /(2 m-6)$ or $n /(2 n+6)$. In order to facilitate calculations and comparisons when $\mathrm{m}$ and $\mathrm{n}$ were large, the ratio of carbon to hydrogen was simplified as 1:2 (calculated by $\mathrm{CH}_{2}$ ); in other words, the degradation per $1 \mathrm{M} \mathrm{C}(12 \mathrm{~g})$ gives the equivalent of $14 \mathrm{~g}$ of oil degraded. According to this proportion, the VOC amount of each system was converted into the amount of oil.

\section{VOC Measurement and Calculation}

In this study, a GSM7240 ppb level VOC analyzer measured the amount of VOCs in each system. VOC values in each system were directly obtained (expressed as the amount of C) and converted into an amount of oil, and were then used to evaluate oil removal by VOCs for each system in units of $\mathrm{mg} / \mathrm{kg}$.

\section{Pollutant Half-Life Prediction}

Half-life of petroleum contaminants in soil during bioremediation was an important indicator to study the efficiency of bioremediation and to develop the recovery strategy for soil function. Assuming that the overall microbial degradation of residue follows the first-order reaction [16], the half-life of petroleum contaminants was predicted for each simulation system. The mathematical relationship is shown in Equation (3):

$$
\frac{d C}{d t}=K_{t} C
$$

...where $\mathrm{C}$ is the concentration of oil in soil (\%), $\mathrm{t}$ represents degradation time $(\mathrm{d})$, and $\mathrm{K}_{\mathrm{t}}$ refers to the constant of biodegradation rate $\left(\mathrm{d}^{-1}\right)$. By using these parameters we can calculate Equation (4):

$$
\ln \frac{C}{C_{0}}=-K_{t}
$$

Making a straight line with time as the abscissa, $\operatorname{lnC}$ as the vertical axis, and $\operatorname{lnC}_{0}$ as the intercept, $\mathrm{K}_{\mathrm{t}}$ is the slope of the line. Then the half-life of oil for each system was calculated by the half-life formula as shown in Equation (5):

$$
t 1 / 2=\ln 2 / K_{t}
$$

\section{Results and Discussions}

Volatilization is the main method to remove crude oil in the sterilization system. The other four systems used similar methods to remove oil; however, they also incorporated other removal approaches such as biodegradationproducing intermediates and mineralization, which completely converted the oil into $\mathrm{CO}_{2}$.

\section{Removal Efficiency Analysis}

\section{Total Removal Efficiency of Crude Oil}

Oil removal rate was a direct parameter in the evaluation of the efficiency in bioremediation of the simulation systems. The content of oil in the soil at different periods in each system was measured by ultrasonic and Soxhlet extraction, and then the total removal rate of oil in the simulation systems was calculated. The results are shown in Fig. 2.

Fig. 2 shows that the total removal rate of the sterilized system was $8.87 \%$ after 91 days operation, and the rate of the oxygenated and water-controlled system was $17.66 \%$. The N/P-adjusted system's removal rate reached $29.40 \%$, and the rate of the broth-added system was $32.03 \%$. Finally, the double-broth-added system's rate was $34.23 \%$ 


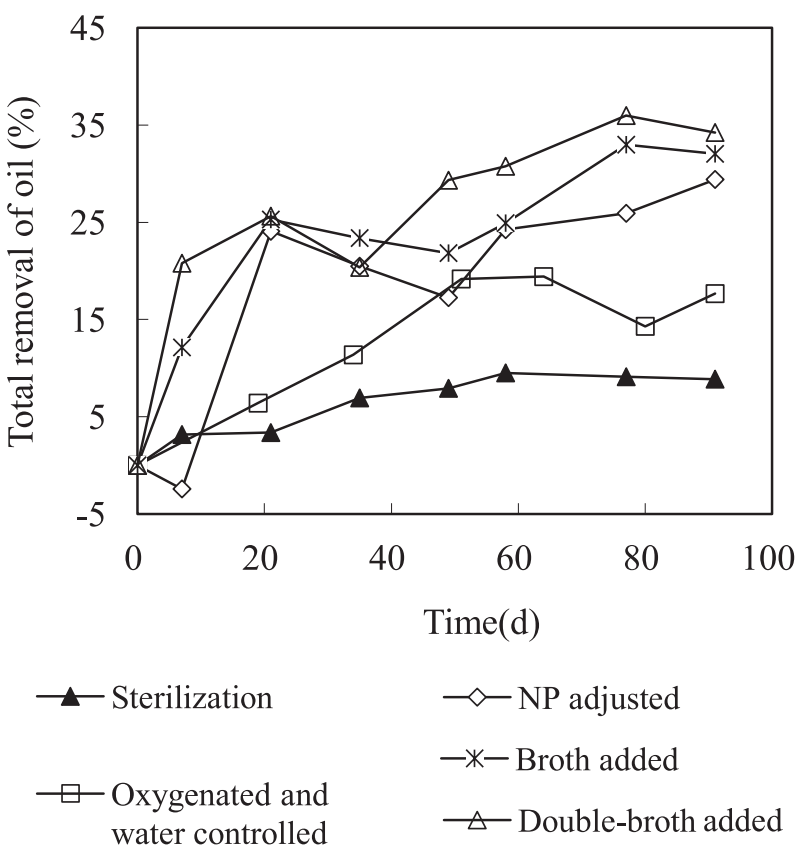

Fig. 2. Total removal of oil in the simulation systems.

in oil removal, and it also had the highest removal rate, which was 3.9 times that of the sterilization system. Adding function microbial can significantly increase the removal of crude oil [17]. The total oil removal rate of the $\mathrm{N} / \mathrm{P}$-adjusted system was 1.7 times that of the oxygenated and water-controlled system. Adding enrichment broth did not make as significant a difference as adding nutrients to increase the removal rate of crude oil, and the removal of the other two broth-added systems were only 1.1 times to 1.2 times that of the N/P adjusted system after 91 days of operation. Clearly, biodegradation had a major effect on the removal of oil in the simulation system, deducting the impact of volatile oil removal.

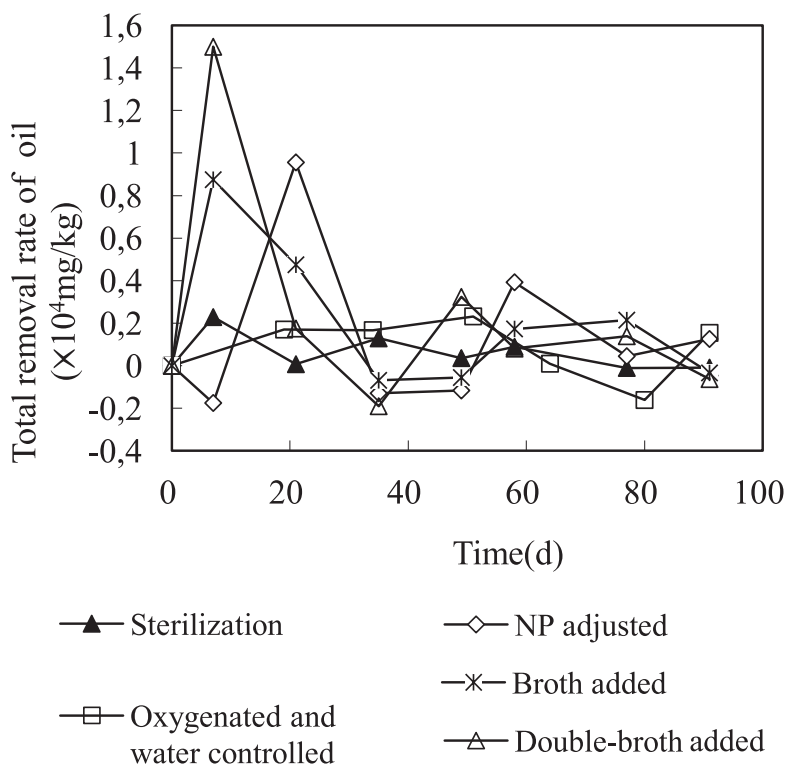

Fig. 3. Total removal rates of oil in the simulation systems.
Oil removal in the simulation systems at different operation times was analyzed. The removal dynamic for each system is shown in Fig. 3.

Compared to other bioremediation, the total removal rate of crude oil in the sterilization system was at a low level during the experiment, which had no contribution to the action of microorganisms (Fig. 3), and suggested that the crude oil was essentially removed by volatilization. The total oil removal rate in the oxygenated and watercontrolled system was slightly higher than that of the sterilization system with larger variation. The total oil removal rate of the N/P-adjusted system was very low after the initial 15 days, but it increased rapidly after this time point and had no significant difference from the microbial enrichment added systems. The total oil removal rate of the two sets of broth systems was high during the initial 15 days with the highest rate at 10 times that of the N/Padjusted system; however, there was little difference from the N/P-adjusted system after 30 days.

It is clear there was a certain lag of about 10-15 days for crude oil removal in the N/P-adjusted system in this study. Adding enrichment broth can improve the oil removal rate in the early days, but it lends only a small contribution to the long-term oil removal rate. The reason for this phenomenon is that adding a large number of enrichment broth-containing oil-degrading microorganisms can improve the initial number of microorganisms and make system microbes multiply rapidly. As the system runs and becomes stable, the native microorganisms bloomed in tested soil, which made microbial numbers and activity reach a higher level, and added enrichment broth had a relatively insignificant advantage at this time.

\section{Removal Efficiency Analysis of Crude Oil Components}

The efficiencies of biodegradation of different contaminants with different components were inconsistent during the biodegradation process of complex oil components caused by the different bioavailabilities, eventually leading to different removal efficiencies of different components of oil contaminants [18].

The removal of different components of crude oil in each simulation system was different. Overall, the main effector of oil component removal in each analog system was alkanes, aromatics, and other light components. When the control measures were increased, the removal of alkanes increased rapidly. By calculating the removal efficiency of alkanes relative to the total removal of oil in each simulation system, the removal of alkanes in the sterilization system was $4.36 \%$ after 91 days of operation; that in the oxygenated and water system was $9.11 \%$; in the N/P-adjusted system, the efficiency was $23.17 \%$; that in the broth-added system was $25.54 \%$; and in the double-broth-added system was $26.73 \%$, which accounted for $50 \%$ to $80 \%$ of the total removal of crude oil in the corresponding systems. The highest total removal of alkanes in the double-broth-added system was six times that of the sterilization system. Overall, we found that 
the main components of oil-biodegradation were alkanes and aromatics, with the alkanes being the dominant component.

\section{Mechanisms of Enhanced Bioventing Remediation}

In this study, the removal of crude oil included volatilization and biodegradation. The biodegradation of oil included completely mineralized and intermediate products in the bioremediation system [19]. The completely mineralized section was calculated by the measurement of $\mathrm{CO}_{2}$ absorption [20], and the intermediate section included VOC increments of volatile components that were broken down into small molecules and discharged in the oxygenated process and the residue intermediates in the soil. The volatile intermediates of biodegradation (VOCs incremental) will be discussed later. Due to the difficult separation with initial contaminants, the intermediate residues in the soil were difficult to quantify accurately on volume and material composition. Therefore, this aspect of the analysis was not included in evaluating the efficiency of biodegradation in this study.

\section{Volatilization of Crude Oil During Bioventing Remediation Process}

Some VOCs of small molecules from crude oil were discharged with the air during the power oxygenation process in the simulation system. The volatilization amount of crude oil caused only by the venting process can be measured by the sterilization system. In this system, there was no biodegradation, which means the value of VOCs obtained from this system was only through the volatilization process.

We determined that the total volatilization amount of oil components caused by the power-oxygenated system was composed of the total VOCs in each simulation system, and that the volatilization amount of the oil components caused by physical and chemical processes were background values of the VOCs. There was no microorganism in the sterilization system and the only way to produce VOCs was the dynamic oxygen-filling process. Therefore, the total VOCs of this system, which also was the background value, were $0.37 \times 10^{4} \mathrm{mg} / \mathrm{kg}$ after 91 days of operation.

Through the whole experiment, the generation of VOCs was unavoidable for the objective existence low molecular weight organic matter in the crude oil-containing soil. In addition, vacuum pumping made the volatilization easier.

\section{Intermediate Product of Crude Oil in Bioventing System}

For the oxygenated and water-controlled, N/Padjusted, broth-added, and double-broth-added systems, microbial degradation increased the proportion of small molecules released and further increased the generation and volatilization of VOCs.

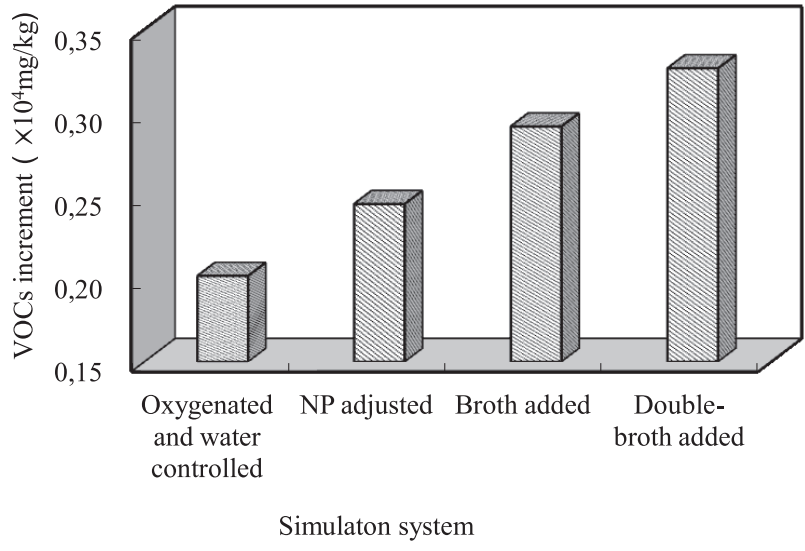

Fig. 4. VOC increment of bioremediation in the simulation systems.

The change in VOC increments in the four sets of bioremediation systems caused by microbial degradation was calculated by subtracting the background values obtained for the total VOCs. The VOC increments of the four sets of bioremediation systems after 91 days of operation are shown in Fig. 4.

The increment of VOCs generated by biodegradation varied in the four systems: oxygenated and water-controlled was $0.20 \times 10^{4} \mathrm{mg} / \mathrm{kg}$, N/P-adjusted was $0.25 \times 10^{4} \mathrm{mg} / \mathrm{kg}$, broth-added was $0.29 \times 10^{4} \mathrm{mg} / \mathrm{kg}$, and double-broth-added was $0.33 \times 10^{4} \mathrm{mg} / \mathrm{kg}$. Thus, the double-broth-added system showed the highest increment at 1.2 times that of the oxygenated and water-controlled system (Fig. 4).

\section{Mineralization of Crude Oil in Bioventing Systems}

The amount of crude oil mineralization was measured and calculated in bioremediation systems at different periods, as shown in Fig. 5.

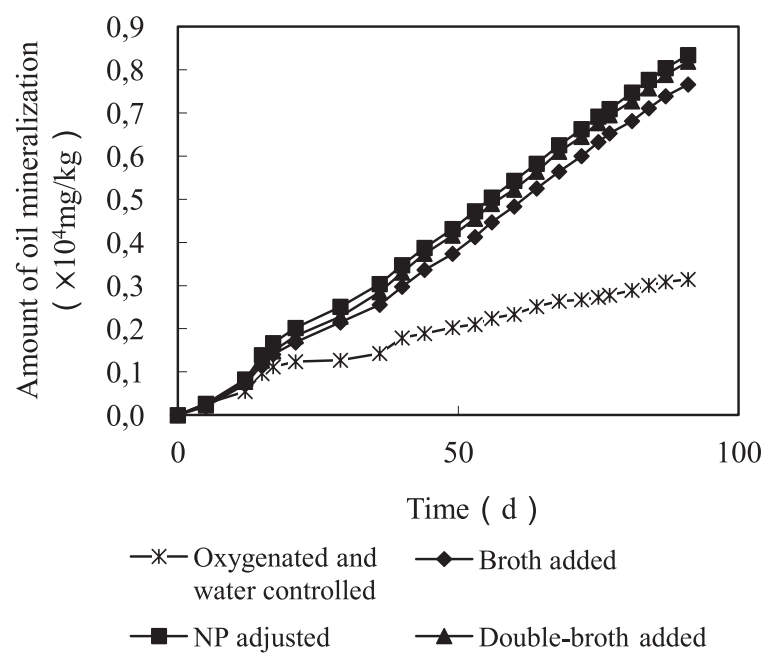

Fig. 5. Amount of oil mineralization in the bioremediation simulation systems. 
The mineralization in the oxygenated and watercontrolled system was $0.32 \times 10^{4} \mathrm{mg} / \mathrm{kg}$, which was relatively weak. The mineralization in N/P-adjusted, broth-added, and double-broth-added systems were $0.83 \times 10^{4} \mathrm{mg} / \mathrm{kg}, 0.77 \times 10^{4} \mathrm{mg} / \mathrm{kg}$, and $0.82 \times 10^{4} \mathrm{mg} / \mathrm{kg}$, respectively. These values were relatively high and about 2.6 times that of the oxygenated and water-controlled system (Fig. 5). From the figure, we could determine that the amount of mineralization between the N/P-adjusted system and double-broth-added system were almost the same in the whole process. Indeed, regulating $\mathrm{N}$ and $\mathrm{P}$ can effectively strengthen the mineralization action of microorganisms on crude oil and increase mineralization efficiency of oil in soil during the oil biodegradation process. Compared with the N/P-adjusted system, the mineralization amount of the broth-added system was unchanged. This might be because the main limiting factor for degradation was the nutrition in the crude oil-polluted soil, thus adding microbial enrichment had no substantial improvement to the mineralization of oil.

Fig. 6 presents the crude oil mineralization rates of microbial action in each bioremediation system, and indicates that the oil mineralization rate of bioremediation was essentially the same during the initial 15 days (the acclimation period for the system) [21]. The mineralization rate increased rapidly after the system booted and reached the highest rates after 15 days. The mineralization rate was stable after 15-20 days in each system. The oil mineralization rate of the oxygenated and water-controlled system was low during the stable operation, which was only $0.002 \times 10^{4} \mathrm{mg} /(\mathrm{kg} \cdot \mathrm{d})-0.004 \times 10^{4} \mathrm{mg} /(\mathrm{kg} \cdot \mathrm{d})$. The mineralization rates of the other three strengthened systems were relatively higher compared to the oxygenated and water-controlled system, and stabilized at $0.007 \times 10^{4} \mathrm{mg} /$ $(\mathrm{kg} \cdot \mathrm{d})-0.01 \times 10^{4} \mathrm{mg} /(\mathrm{kg} \cdot \mathrm{d})$ levels that were $3-5$ times that of the oxygenated and water-controlled system. Through the control of the micro-ecological environment, the adaption of microorganisms during the system operation was improved. Thus the three strengthened systems had

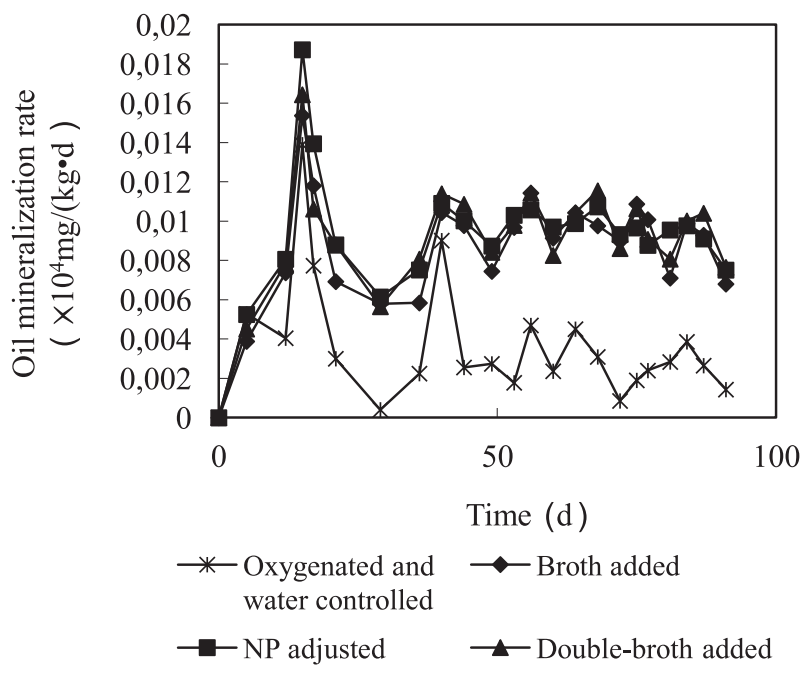

Fig. 6. Oil mineralization rates of bioremediation systems during different time periods. larger amounts of microbial degradation bacterium due to the added $\mathrm{N}$ and $\mathrm{P}$, and the enrichment broth which made the higher mineralization amount and rate. Clearly, adding $\mathrm{N}$ and $\mathrm{P}$ nutrients can greatly improve the mineralization rate of crude oil, but adding enrichment broth had no obvious effect.

We determined from this study that in the process of mineralization the most important factor is the N/P nutritional level. For the soil with crude oil, adjusting the environment for the indigenous microorganisms such as controlling the $\mathrm{O}_{2}$ and $\mathrm{H}_{2} \mathrm{O}$, and adding $\mathrm{N}$ and $\mathrm{P}$ could effectively enhance the mineralization process, which was the main way to reduce crude oil in biodegradation.

\section{The Comprehensive Mechanism of Crude Oil Biodegradation in Simulation Systems}

Through the above discussion and analysis of crude oil degradation of each simulation system, the removed oil in each system mainly included volatile VOCs as background values, and a biodegradable portion mainly composed of mineralization and volatile intermediate products. Therefore, combined with the above analysis of power-oxygenated volatilization, the role and efficiency of biodegradation of oil in soil for each simulation system, and the role and the proportion of crude oil removal in different oil removal processes such as volatilization and biodegradation can be calculated in contaminated soil. In addition, the effect of oil biodegradation can be preliminarily evaluated.

The effect of crude oil biodegradation in different simulation systems was comprehensively evaluated and shown in Fig. 7, which indicated that the removal of crude oil in the soil in the sterilization system was mainly caused by volatilization. The removal of crude oil in soils in the other four sets of bioremediation systems was caused by volatilization and biodegradation, in which biodegradation was the main effector, and reached the highest proportion of $73.31 \%$ in the N/P-adjusted system. This showed that bioremediation efficiency can be effectively improved by regulating the micro-ecological environment in simulation systems. Adding enrichment broth can increase the total

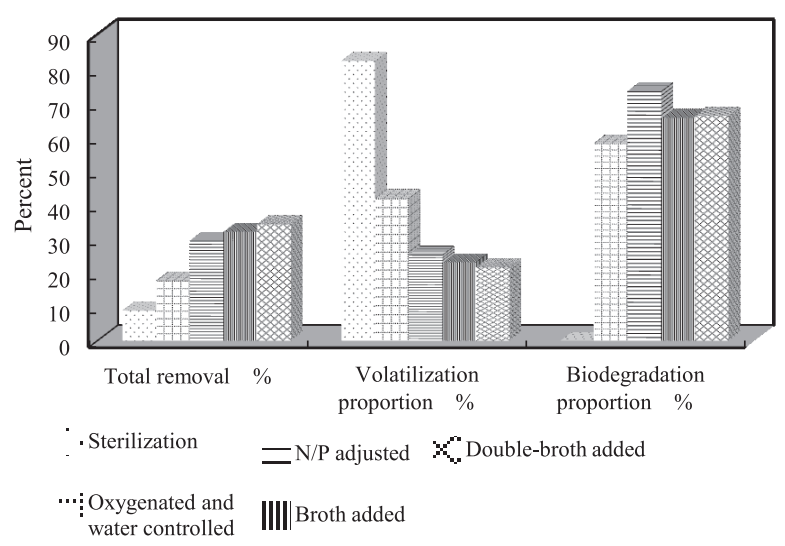

Fig. 7. Integrated analysis of the mechanism of oil-degradation in the simulation systems. 


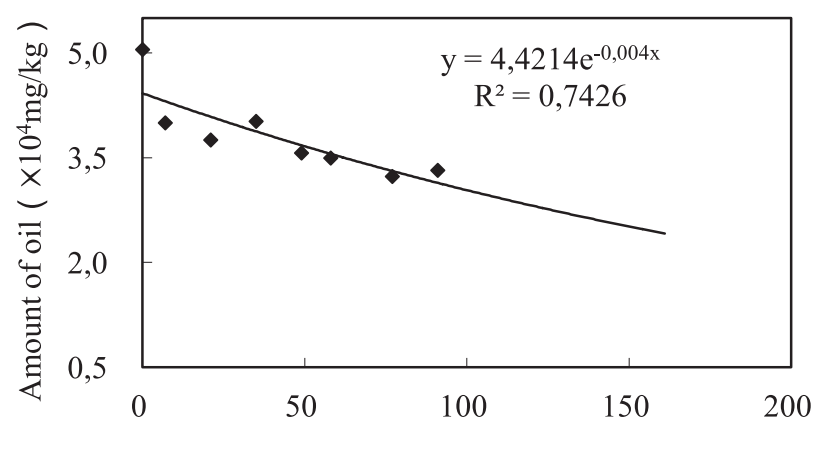

Time ( d )

Fig. 8. Curve fitting of oil-biodegradation in the double-brothadded system.

removal of oil, but it has little influence on biodegradation compared with the N/P-adjusted system.

Through the whole bioventing process including volatilization and biodegradation, the removal of crude oil mainly depended on the latter part in which the indigenous crude oil degrading microorganism played the primary role. Based on controlling the water and $\mathrm{O}_{2}$, adding $\mathrm{N}$ and $\mathrm{P}$ can effectively increase the removal rate of crude oil. Especially in the completely mineralized section, the levels of $\mathrm{N}$ and $\mathrm{P}$ were the leading factor influencing mineralization amount and rate.

\section{Half-Life Prediction of Residual Crude Oil in Soil Environments}

The bioremediation of the actual soil contaminated with residual crude oil was a slow process that resulted in a long bioremediation cycle. In this study, the contaminated soil came from an actual oilfield and a prediction for the remediation cycle was carried out by calculating the half-life of the bioremediation that could guide the actual bioremediation of the residual crude oil in the soil environment.

The dynamic changes of total oil content of soil in the simulation system were fitted during different operating periods [22-23]. Fig. 8 shows the results of a representative double-broth added system.

In simulation systems, the changes in operation time of crude oil content in soil followed first-order kinetics, combining literature [24]. In addition, by making a similar analysis in other simulation systems, $\mathrm{K}_{\mathrm{t}}$ was calculated in each analogue system. The half-life of oil-biodegradation of each simulation system was calculated based on Equation (5), and the results are shown in Table 4.
Compared with the two sets of broth-added systems, the oil biological efficiency of the N/P-adjusted system was comparative and the half-life of oil was also substantially the same. However, the N/P-adjusted system did not need the preparation of enrichment broth, which was a relatively cost-effective strengthening measure for bioremediation of oil-contaminated soil and dropped the half-life of oil to 192 days.

\section{Conclusions}

Our investigation of bioremediation simulation systems showed that the total removal efficiency of crude oil was as high as $34.23 \%$ after 91 days. The velocity of the oxygenated and water-controlled system was a little bit higher than the sterilized system, which also had slightly greater volatility. The N/P adjusted system had a low removal rate in the first 15 days, but it increased quickly after that and showed no differences with the brothadded system in the later days of the experiment. Thus, compared with the broth-added and double-broth-added systems, the N/P-adjusted system had a certain lag phase that was about 10-15 days in this study. The main way to remove crude oil in the bioremediation simulation system was biodegradation, which accounted for $73.31 \%$ of the total removal rate. Additionally, mineralization was the key to biodegradation and was responsible for up to $60 \%$ of the removal rate. Alkane was the main content in crude oil that was degraded and was $50-80 \%$ of the degraded content. Based on the analysis of the biodegradation of oil in the bioremediation system, the N/P-adjusted system, the broth-added system, and the double-broth-added system had high levels in the amount of crude oil mineralization. In stable system operation the mineralization of crude oil was about 2.6 times that of the oxygenated and watercontrolled system. The mineralization rate was about 3-5 times that of the oxygenated and water-controlled system. Thus, we can see that adjusting the content of $\mathrm{N}$ and $\mathrm{P}$ can effectively improve mineralization and increase the mineralization rate. Currently, adjusting water, temperature, oxygen content, N/P content, and adding broth can shorten the half-life of crude oil-contained soil in the simulation system down to 182 days.

\section{Acknowledgments}

The authors would like to thank the National Basic Research Program of China (973 Program, No. 2014CB238906) for financial support.

Table 4. Half-life of oil-biodegradation in the simulation systems.

\begin{tabular}{|c|c|c|c|c|c|}
\hline Simulation system & Sterilization & Oxygenated and water-controlled & N/P-adjusted & Broth-added & Double-broth-added \\
\hline $\mathrm{K}_{\mathrm{t}}\left(\mathrm{d}^{-1}\right)$ & 0.0010 & 0.0021 & 0.0036 & 0.0035 & 0.0038 \\
\hline Half-life $(\mathrm{d})$ & 693 & 330 & 192 & 198 & 182 \\
\hline
\end{tabular}




\section{References}

1. YUAN J.M., YANG D.M., X H., CHEN L. Progress in research on bioremediation of oil-contaminated soil. Environmental Engineering. 31, 797, 2014.

2. CHEN M., XU P., ZENG G.M., YANG C.P., HUANG D.L., ZHANG J.C. Bioremediation of soils contaminated with polycyclic aromatic hydrocarbons, petroleum, pesticides, chlorophenols and heavy metals by composting: Applications, microbes and future research needs. Biotechnol Adv. 33 (6), 745, 2015.

3. GOGOI B.K., DUTTA N.N., GOSWAMI .P, KRISHNA MOHAN T.R. A case study of bioremediation of petroleumhydrocarbon contaminated soil at a crude oil spill site. Adv Environ Res (Oxford, U.K.).7 (4), 767, 2003.

4. QIN G., GONG D., FAN M.Y. Bioremediation of petroleumcontaminated soil by biostimulation amended with biochar. Int Biodeterior Biodegrad. 85, 150, 2013.

5. LIU P.W.G., CHANG T.C., CHEN C.H., WANG M.Z., HSU H.W. Effects of soil organic matter and bacterial community shift on bioremediation of diesel-contaminated soil. Int. Biodeterior Biodegrad. 85, 661, 2013.

6. MORI Y., SUETSUGU A., MATSUMOTO Y., FUJIHARA A., SUYAMA K. Enhancing bioremediation of oilcontaminated soils by controlling nutrient dispersion using dual characteristics of soil pore structure. Ecol Eng. 51, 237, 2013.

7. XU Y., SUN G.D., JIN J.H., LIU Y., LUO M., ZHONG Z.P., LIU Z.P. Successful bioremediation of an aged and heavily contaminated soil using a microbial/plant combination strategy. J Hazard Mater. 264, 430, 2014.

8. WINQUIST E., BJÖRKLÖF K., SCHULTZ E., RÄSÄNEN M., SALONEN K., ANASONYE F., CAJTHAML T., T. STEFFEN K., S. JØRGENSEN K., TUOMELA M. Bioremediation of PAH-contaminated soil with fungi From laboratory to field scale. Int. Biodeterior. Biodegrad. $\mathbf{8 6}, 238,2014$

9. XU J.L., HUANG T.L., TANG Z.X., XIAO Z.Q. Isolation of petroleum degradation bacteria and its application to bioremediation of petroleum-contaminated soil. Acta Scientiae Circumstantiae. 27 (4), 570, 2009.

10. NIKOLOPOULOU M., PASADAKIS N., NORF H., KALOGERAKIS N. Enhanced ex situ bioremediation of crude oil contaminated beach sand by supplementation with nutrients and rhamnolipids. Mar Pollut Bull. 77 (1-2), 37, 2013.

11. JEONG S.W., JEONG J., KIM J. Simple surface foam application enhances bioremediation of oil-contaminated soil in cold conditions. J Hazard Mater. 286, 164, 2015.

12. SUI HONG, LI X. Modeling for volatilization and bioremediation of toluene-contaminated soil by bioventing. Biotechnology and Bioengineering, 19, 2, 2011.

13. ANTÔNIO THOMÉ., ASCE M., CLEOMAR REGINATTO; IZIQUIEL CECCHIN, LUCIANE MARIA COLLA. Bioventing in a residual clayey soil contaminated with a blend of biofiesel and diesel oil. J. Environ. Eng. 140, 11, 2014.

14. GONG X.B. Remediation of weathered petroleum oilcontaminated soil using a combination of biostimulation and modified Fenton oxidation. Int Biodeterior Biodegrad. 70, 89, 2012.

15. FERRADJI F.Z., MNIF S., BADIS A., REBBANI ., FODIL D., EDDOUAOUDA K., SAYADI S. Naphthalene and crude oil degradation by biosurfactant producing Streptomyces spp. isolated from Mitidja plain soil (North of Algeria). Int Biodeterior Biodegrad, 86, 300, 2014.

16. CHEMLAL R., TASSIST A., DROUICHE M., LOUNICI H., DROUICHE N., MAMERI N. Microbiological aspects study of bioremediation of diesel-contaminated soils by biopile technique. Int Biodeterior Biodegrad. 75, 201, 2012.

17. YONGRUI P.I., LONG MENG., MUTAI BAO., PEIYAN SUN., JINREN LU. Degradation of crude oil and relationship with bacteria and enzymatic activities in laboratory testing. Int. Biodeterior. Biodegrad. 106, 106, 2016.

18. FRANCO I., CONTINA M., BRAGATO G., NOBILI M.D. Microbiological resilience of soils contaminated with crude oil. Geoderma. 121(1-2), 17, 2004.

19. MOUBASHER H.A., HEGAZY A.K., MOHAMED N.H., MOUSTAFA Y.M., KABIEL H.F., HAMAD A.A. Phytoremediation of soils polluted with crude petroleum oil using Bassia scoparia and its associated rhizosphere microorganisms. Int Biodeterior Biodegrad. 98, 113, 2015.

20. LIANG Y.T., ZHANG X., DAI D.J., LI G.H. Porous biocarrier-enhanced biodegradation of crude oil contaminated soil. Int Biodeterior Biodegrad. 63 (1), 80, 2009.

21. RAGHEB A. TAHHAN, ROUBA YOUSSEF ABU-ATEIH. Biodegradation of petroleum industry oily-sludge using Jordanian oil refinery contaminated soil. International Biodeterioration \& Biodegradation, 63, 2009.

22. WU G.Z., COULON F., YANG Y.W., LI H., SUI H. Combining Solvent Extraction and Bioremediation for Removing Weathered Petroleum from Contaminated Soil. Pedosphere. 23 (4), 455, 2013.

23. LIN M., HU X.K., CHEN W.W., WANG H., WANG C.Y. Biodegradation of phenanthrene by Pseudomonas sp. BZ3 , isolated from crude oil contaminated soil. Int Biodeterior Biodegrad. 94, 176, 2014.

24. VASSALLO A.M. Study of the oxidation of oil shale and kerogen by Fourier transform infrared emission spectroscopy. Energy Fuels. 12, 682, 1998. 